\title{
Health-Care Waste: Diagnosis and Possibility of Application of Reverse Logistics on a Dental Clinic
}

\author{
E. O. A. Ribeiro and R. K. Vieira
}

\begin{abstract}
Management of the waste related to environmental issues becomes increasingly essential for maintaining a healthy environment, and the waste of health services are part of this system that should be well planned and solved. The objective of this work is to make the diagnosis of management of dental waste production chain system in a dental clinic in the city of Manaus and check the possibility of application of reverse logistics. A single case study was conducted, with an exploratory, qualitative and observational approach, empirically, the management of waste production chain system. The management plan is a reality in the studied public health unit and complies with current legislation; however, the application of reverse logistics still does not occur. The relevance of the plan compliance assists in preserving the environment and health of the population, minimizing health and environmental risks, and demonstrates the importance of proper management of this waste.
\end{abstract}

Index Terms-Healthcare waste, management plan, reverse logistic.

\section{INTRODUCTION}

Nowadays, serious challenges are faced regarding the waste produced by human beings, such as the complexity and diversity within environmental issues [1].

Environmentalists point out that the issue of waste is already one of the most serious urban environmental problems of today [2]. The environmental management is a matter of general interest. It is due the concern with the development of a sustainable model for production and consumption. This interest has generated more efforts of international and national organizations. This organizations have invested a significant proportion of theirs resources to protect the environment and to provide a specific legislation [3]. It is need a management associated with the environmental issues to allow the environmental protection. Thus, the Waste Management becomes increasingly critical.

More broadly, sustainable waste management involves many processes, people, laws, and it is not constantly developed effectively.

Health-care waste $(\mathrm{HCW})$ requires special attention and proper management techniques. It is due the potential pollutant of the environment and infectious environment from human health [4]. Therefore, $\mathrm{HCW}$, as well as waste in general, should have their management and design well harmonized.

Gomes and Esteves [5] argue that the $\mathrm{HCW}$ poses a serious

Manuscript received November 3, 2016; revised February 6, 2017.

The authors are with Federal University of Amazonas, Manaus, Brazil (e-mail: elianearanha@hotmail.com,kennedy71@gmail.com). problem for society and the environment. It is due to its toxic and/or pathogenic characteristics. Shinzato et al. [6] attentive to the need to require a management plan appropriate for $\mathrm{HCW}$, because the issues of public health and environmental sanitation. Thus, it is noticeable a worldwide concern regarding the management of $\mathrm{HCW}$.

According to the Environmental Protection Agency of the United States (EPA) [7], HCW is all waste generated at health care facilities, such as hospitals, physicians' offices, dental practices, blood banks, and veterinary hospitals/clinics, as well as medical research facilities and laboratories.

HCW Management practices vary greatly from country to country. It depends on several factors such as socio-economic conditions, regulation, level of education, available resources, treatment technologies, and the capacity to monitor and best manage inadequate practices [8].

Dental waste constitutes a small part of the total solid waste produced by the community. However, its management is important, because it includes various potentially infectious and hazardous materials [9].

Inadequate and inappropriate handling of dental health-care waste may have serious public health consequences and a significant impact on the environment. It is considering the growing number of dentists in urban areas and increased awareness about the dental treatment of the public [10]

Reverse logistics (RL) awakens a growing interest in business organizations in order to internalize their performance in a global. It is due the increasing demand for an economically viable, environmentally sustainable and socially just management, competitive and continuously market changing [11]. Thus, the use of logistic management will boost, as well as possible environmental gain and public health.

Not withstanding the fact that environment issues have been a concern of nations [12]. RL is still not widely used in health care, nevertheless it is waited that the implementation of RL promotes less waste.

Analysis of reverse management $\mathrm{HCW}$ brings to the scientific knowledge a systemic and integrated view on problem of discarded materials. It is possible to comprehend how the distributor, generator of waste and final disposal are inserted in the same chain, in which all are responsible. To know this network, it requires a scientific method, systematic and replicable. Which it needs to expand applications, and adding knowledge to develop a reverse logistic system [13].

Therefore, the aim of this work performs the diagnosis of the management system of the production chain of dental waste in a dental clinic. 


\section{Health-CARE WASte}

Over the past 15 years, there has been much effort to improve the Health-care Waste Management (HCWM) policies and disseminate them nationally and internationally [14]-[16].

However, there is no agreement accepted worldwide on the definition of $\mathrm{HCW}$, which represents a challenge from the similar point of view [17]. Most definitions refer to a fraction of the waste generated by medical activities.

The EPA/USA defines HCW as Hospital Waste, with Medical Waste being used when the waste is hazardous, and Regulated Medical Waste, when infectious. In addition, there are also significant differences in the HCWM worldwide, mainly between low and high-income countries [18].

Many developed nations have specific legislation regarding HCWM, but there isn't much explanation about which ones are classified as infectious [19].

In Brazil, for example, the HCW covers all medical waste.

Legislation on the HCWM is a key weakness in the governance structures, particularly in low-income countries, and in need of support for institutional strengthening and capacity building [8], [20], [21].

Several health centers, in developing countries, do not adequately perform an HCWM. It is a problem especially for the infectious and hazardous waste. This waste is not sufficiently segregated at the time of disposal [15]. This makes HCWM a significant public health and the environmental problem [22]. According to Hossain et al. [17] HCWM remains a major challenge, particularly in most health facilities in developing countries.

Exposure to hazards associated with $\mathrm{HCW}$ and its management have gained attention worldwide in various conferences, symposiums, forums, national and international [23].

If this waste is not properly managed, it can be of high risk to hospital staff, patients, the community, public health and the environment, especially in populations with low purchasing power, where disposal standards often are not followed [24].

In 2011, a report presented to the United Nations Organization (ONU), recognized concern with inadequate management and disposal of medical waste, including open burning. Even though on a small scale, these burnings endangers the environment [25].

The CDC (Center for Disease Control) and EPA regulate the HCW in the USA, and organizations such as WHO (World Health Organization) and PAHO (Pan American Health Organization) have their own classifications systems.

In Brazil, the Sanitary Vigilance Agency (SVA) and the National Council for the Environment (NCE) assumed the role of guide, define rules, and take action. This actions could be through the imposing legal liability for the proper discharge of hazardous waste, from its generation to final disposal [26].

HCW, in Brazil, are classified according to the Resolution of the Collegiate Board (RCD) 306/2004 [27] into five groups: A (biohazard), B (chemical), C (radioactive), D (common) and E (sharps). The RDC commands the health facilities to implement a management of HCW by establishing an Health Care Waste Management Plan
(HCWMP). In developed countries, as well as own classification systems for $\mathrm{HCW}$, is invested a lot in environmental education on the particular collection, recycling and research so that we can reuse waste discarded.

It's important to highlight that the solid waste generated by health care establishments is a source of microorganisms and the handling, storage, transport and improper disposal can lead to accidents, infectious diseases, in addition to causing damage to the environment [28]. Therefore, an adequate management is required to a better world.

The importance of HCWM is a fact, but there are difficulties in its operation, from the inexperience of municipalities and hospital managers to effectively equate its provisions, to the diversity of rules and regulations on the subject [29]. Developing a HCWMP aimed at the right management of waste as well as the appropriate final destination, minimize the risks of health and environmental pollution.

A HCWMP is, according to Mozachi [30], an instrument designed to establish each stage of the waste management process: classification, segregation (separation), conditioning, internal and external collection, transport, storage, treatment and final disposal, and also the safe handling and personal protective equipment use (PPE).

All HCW generators should design and implement a HCWMP taking into account the current legislation and standards of health monitoring. It should prepare by qualified professionals [31].

Dentists and their support staff generally use certain substances that are regulated under federal, state or local environmental regulations [32].

In this perspective, the dentist is responsible for the waste generated by their work process, and to develop actions aimed at meeting the objectives prescribed by law [33]. Hence, the correct segregation in dental offices, with its personnel properly trained, promotes less damage to the environment.

\section{REVERSE LOGISTICS}

Reverse Logistics (RL) is defined, according to the National Policy on Solid Waste (NPSW), as an economic and social development tool characterized by a set of actions, procedures and means to enable the collection and waste recovery solid the business sector, for reuse in its cycle or other productive cycles, or another disposal environmentally appropriate [34].

Nowadays, there are many definitions of RL. The new business opportunities related to sustainable area determine a growing corporate, governmental and researchers interest, to minimize the degradation of the environment [35].

According to Cometti and Alvez [36], RL can contribute to sustainable development because it reduces the consumption of virgin raw materials and environmental contamination risks, creates more jobs due to reversed distribution channels, enables the reuse and recycling of returned products and disseminates environmental responsibility to waste generators.

Therefore, RL relates to all logistics activities including collect, remove and process products using part of products 
and / or materials, in order to ensure a sustainable recovery from an environmental point of view [37].

RL aims to reuse solid waste, thus consuming less natural resources and reducing the environmental impact [38].

The importance of RL takes on the finding of an increase of, between 2002 and 2009, the generation of solid waste in Brazil higher than the growth of population and GDP (Gross National Product) [39].

To minimize the environmental problems associated with the disposal of solid waste, Agenda 21 considers the 3Rs (reduce, reuse, recycle) practice as essential to minimize impacts to the environment in landfills [40].

RL inclusion at waste management brought a promising opportunity to reduce environmental impacts in the production cycle, systematizing the waste and co-products flow through its reuse in or outside the production chain [41].

To Better Understand The Waste Production Chain And Its Management In A Sustainable And Secure Way, From The Perspective Of Economic Gain And Promotion Of Public Health, The Adoption Of Logistics Management Is Necessary, In Order To Include The Relevant Variables [13].

The use of RL concepts generates certain environmental benefits. The use of reverse distribution channels properly structured and organized, promote the minimization of waste generation, from an efficient segregation and treatment methods that seek to reduce the volume of waste to be deposited in soil and exposed to community [12].

Hospital logistics would be, according to RCD 50/2002 [42], a support area with very different functions, ranging from laundry services, maintenance, support for X-ray examinations where there is low contact with patients, to activities greater contact, such as cleanliness and hygiene of the building, parking, security, and surveillance.

Only a few studies point the loss control of hospital and laboratory supplies, given the nature of the provision of medical services and diagnostics [43]. Most health services do not have recycling systems or RL.

And despite the complexity, international and national data demonstrate the importance of logistics in the hospital environment [44].

\section{Methodology}

Initially this work began with a literature review.

A bibliographic / desk research was carried out to obtain a theoretical background through a literature related to the topic.

A single case study of exploratory, qualitative and observational approach was conducted. In this study was analyzed the management system of the dental waste production chain in a dental clinic and integrated them to the reverse logistics.

This paper's objective wasn't to quantify the information collected but to know how the management of HCW was performed.

For study's delimitation, a dental clinic has been chosen, which is part of the public health system of the city of Manaus, Amazonas, located in the south-central area of the city.

The interviews were conducted using a script prepared by
Maranhão et al. [45]. Interviews have been carried out with those responsible for the execution and management of HCW.

The research didn't involve people, but information on the management of $\mathrm{HCW}$, i.e. questions of personal nature was not made, only the organizational ones since the objective was to gather evidence on the waste treatment of the health unit.

To carry out the interviews, it was necessary to visits several places in loco. It was made during the first half of 2016. It was done because it's crucial to discuss the management of solid wastes on site. It is a way to foster the construction of a diagnosis based. In fact, its procedure is done to enable the understanding of how this management is being operational. It additionally is possible to identify its effectiveness to minimize the potential risks to sanitary issues, to the environment and to human health, respecting the established regulations [46]. There was also the informal observation of the site to record the visits with photos and to appreciate the management of waste.

After gathering the data, these were analyzed by content analysis technique introduced by Bardin and for the graphs and tables the software used was MS-Excel for Windows version XP.

The flowchart in Fig. 1 shows, in summary, the method used in this study.

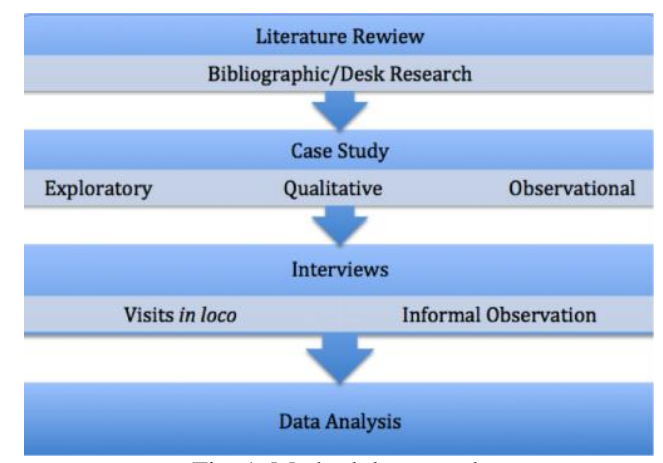

Fig. 1. Methodology used.

\section{RESUlTS AND DISCUSSION}

The results expose a study of the applied questionnaire, the classification and types of waste generated by the dental clinic, the description of the HCWM, and the observation of the possible application of reverse logistics.

The health center has a HCWMP since its inauguration in January 2014 , and it is run by a properly licensed third party company.

The dental clinic is part of State of Amazonas' public health system and is consisted in of twelve dental offices in an area of approximately $90 \mathrm{~m}^{2}$.

Preventive and curative dental services such as consultation, restorations, root canal treatments, scrapings, extractions, cleanings and topical fluoride applications are performed daily.

All clinical procedure in dentistry generates chemical, physical or biological waste and may cause, if not controlled, problems for the patient, practitioners and for the environment [47].

Even if is a small amount of contaminated material from 
the dental waste, there is still a risk of cross-infection and the potential for environmental contamination, when these residues are poorly managed [48], [49].

Several local visits were made for observation and description of the HCWM produced on site. It was done to understand the HCWM process better.

The HCW identified in the healthcare facility belonged to groups A, B, D and E (Table I).

During the visits, it was observed that the waste produced is separated at the moment and at the place of its generation according to its type and characteristics.

The trash bins that were used have a footswitch and were coated with properly identified bags.

Group A residues are packaged in white color bags and identified by the symbol for infectious substances.

Group B HCW that contains Mercury $(\mathrm{Hg})$ is packaged in containers filled with water (Fig. 2) and the fluids, such as developer and fixer solutions, are neutralized by SVA's regulation and then disposed on the sanitary sewer. Lead films disposals, originated from dental radiography, comply with current laws and although they are capable of applying reverse logistic, this doesn't happen (Fig. 3).

TABLE I: HCW GENERATED AT THE CLINIC

\begin{tabular}{|c|c|}
\hline $\begin{array}{l}\text { Groups } \\
\text { A } \\
\text { (Potentially } \\
\text { Infectious) }\end{array}$ & $\begin{array}{l}\text { Description } \\
\text { Gas, cotton, anatomical parts, anesthetic cartridges, } \\
\text { apron, hat, gloves and masks }\end{array}$ \\
\hline $\begin{array}{l}\text { B } \\
\text { (Chemical) }\end{array}$ & Medicines, sanitizers, lead films, Amalgam \\
\hline $\begin{array}{l}\text { C } \\
\text { (Radioactive } \\
\text { Waste) }\end{array}$ & Not applicable \\
\hline $\begin{array}{l}\text { D } \\
\text { (Common Waste) }\end{array}$ & Paper, napkins, plastic, cardboard, disposable cups \\
\hline $\begin{array}{l}\mathrm{E} \\
\text { (Sharps) }\end{array}$ & Syringes, needles, ampoules, scalpel blades, drills \\
\hline
\end{tabular}

Group D waste is packaged in black or dark bags, and there is no separate collection of the general waste.

According to Ozbek and Sanin [48], uncontaminated dental waste is mainly comprised of office waste, which does not contain any substance that may pose a risk to human health or the environment. These types of waste, once they had been provided proper segregation, would be those who might be subject to the application of reverse logistic.

Group E waste is packed in cardboard boxes properly identified and when full they are taken from inside the clinic.

For HCW collection and transport, employees use the full surgical scrub, as well as gloves and proper shoes, besides active immunization against tetanus, diphtheria, hepatitis type B.

Corroborating this study, Santos et al. [50] reported that the appropriate packaging of $\mathrm{HCW}$ is a measure of health promotion, once it prevents accidents, as long as safely handled with the use of personal protective equipment (PPE) and through the right destination. Therefore, it reduces the risks in the workplace, protecting the health of workers and the general population, because prevention is the best way to avoid accidents and reduce harm to public health and the environment.

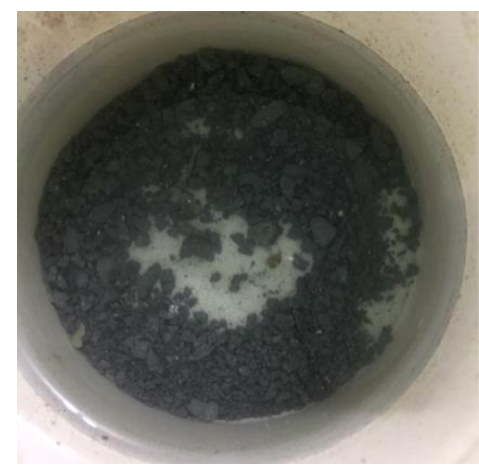

Fig. 2. Amalgam waste.

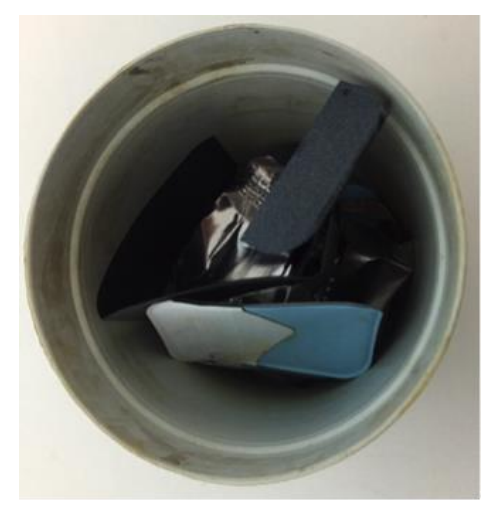

Fig. 3. Waste radiographic films.

Transportation to the temporary external storage is performed in a single direction at the end of each shift and does not coincide with periods of higher flow of people.

There is no waste treatment after removal from inside the room. All treatments performed on $\mathrm{HCW}$ produced at the facility are carried out by a third party.

$\mathrm{HCW}$ is temporarily stored at the facility's outer area, in an exclusive and easily accessible environment. There are two waste shelters in the outdoor area: one for ordinary waste and one for HCW, properly identified.

The transportation of the HCW is made by the hired company, and the universal waste collected daily on a previously agreed scheduled, while hospital waste is collected weekly by a third party enterprise.

Regarding the application of the RL, the result of this study is in agreement with Hanne, Melo and Nickel, [51], [52] research: despite the complexity and importance of logistics, healthcare organizations often underestimate the logistics participation and contribution in a hospital environment.

Therefore, in this paper was observed that wastes from the classes A, B, and E, have biological, chemical and physical characteristics and, can not be recycled or reused, and are sent for disposal in accordance with current legislation. About group D residues, those that could be suitable for recycling or reuse, it was found that there is no segregation at the time of disposal.

This study identified that the dental clinic has an HCWMP since its opening in 2014 and it is run by a third party company in accordance with current legislation.

The waste generated in the unit belongs to groups A, B, D and E. Due to their characteristics, the whole Group D residues and only one from Group B would be capable of applying RL, a fact that doesn't occur.

Regarding the plan's accomplishment, it was observed some failures that need to be fixed, as the absence of 
particular collection and continuing education programs for employees.

Therefore, the HCWMP is a reality in this public health unit, that despite the existence of some gaps, such as the possible application of RL, these might be suggested and then begin to be implemented. The relevance of the plan's accomplishment assists in preserving the environment and people's health, minimizing sanitary and environmental risks, and demonstrates the importance of proper management of this waste.

\section{CONCLUSION}

This study identified that the dental clinic has a HCWMP since its opening in 2014 and it is run by a third party company in accordance with current legislation.

The waste generated in the unit belongs to groups A, B, D and E. Due to their characteristics, the whole Group D residues and only one from Group B would be capable of applying RL, a fact that doesn't occur.

Regarding to the plan's accomplishment, it was observed some failures that need to be fixed, as the absence of selective collection and continuing education programs for employees.

Therefore, the HCMWP is a reality in this public health unit, that despite the existence of some gaps, such as the possible application of RL, these might be suggested and then begin to be implemented. The relevance of the plan's accomplishment assists in preserving the environment and people's health, minimizing sanitary and environmental risks, and demonstrates the importance of proper management of this waste.

\section{REFERENCES}

[1] C. R. D. R. Oliveira, A. Pandolfo, M. S. Martins, A. P. Gomes, L. M. Pandolfo, and L. D. Tagliari, "Proposta para um plano de gerenciamento dos resíduos de serviços de saúde nos estabelecimentos assistenciais de saúde de Guaporé/RS," Revista CIATEC-UPF, vol. 5, no. 1, pp. 1-11, 2013.

[2] M. B. Garcia, J. L. Neto, J. G. Mendes, F. M. F. Xerfa, C. A. B. Vasconcellos, and R. R. Friede, "Resíduos Sólidos: Responsabilidade compartilhada," Semioses, Rio de Janeiro, vol. 9, no. 2, pp. 77-91, 2015.

[3] World Health Organization. (2012). Safe management of wastes from healthcare activities. [Online]. Available: http://www.who.int/water_sanitation_health/medicalwaste/wastemana g/en/

[4] F. Rizzon, C. H. Nodari, and Z. C. Reis, "Desafio no gerenciamento de resíduos em serviços públicos de saúde," Revista de Gestão em Sistemas de Saúde-RGSS, vol. 4, no. 1, 2015.

[5] L. P. Gomes and R. V. R. Esteves, "Análise do sistema de gerenciamento dos resíduos de serviços de saúde nos municípios da bacia hidrográfica do Rio dos Sinos, Rio Grande do Sul, Brasil,' Engenharia Sanitária e Ambiental Rio de Janeiro, vol. 17, no. 4, pp. 413-420, 2012.

[6] M. P. Shinzato, S. C. Hess, G. A. Carvalho, C. M. Sano, D. H. L. Kubota, "Diagnóstico e proposta de gerenciamento dos resíduos sólidos de serviços de saúde do setor de doenças infecto parasitárias do núcleo do hospital universitário da UFMS," $25^{\circ}$ Congresso Brasileiro de Engenharia Sanitária e Ambiental, 2009

[7] Environmental Protection Agency of the United States. (2016). [Online]. Available:

http:// www.epa.gov/wastes/nonhaz/industrial/medical/

[8] A. L. Shannon and A. Woolridge, "Medical waste," Waste. Michigan Department of Natural Resources and Environment, pp. 329-339, 2011.

[9] R. Nabizadeh, H. Faraji, and A. A. Mohammadi, "Solid waste production and its management in dental clinics in Gorgan, northern Iran," Int J Occup Environ Med, 2014, vol. 5, pp. 216-221.
[10] O. N. Baghele, S. Phadke, A. A. Deshpande, J. P. Deshpande, and M. O. Baghele, "A simplified model for biomedical waste management in dental practices - A pilot project at Thane, India," European Journal of General Dentistry, vol. 2, issue 3, September-December 2013.

[11] C. W. Chagas and A. S. D. S. Gracco, "A logística reversa de pós-consumo e a política nacional de resíduos sólidos derivados dos serviços de saúde," Pós em Revista do Centro Universitário Newton Paiva, vol. 2, no. 6, pp. 14-22, 2012.

[12] F. P. Souza, M. G. Jacintho, I. T. Silva, and K. P. G. Viana, "Viabilidade da aplicação da logística reversa no gerenciamento dos resíduos dos serviços de saúde: um estudo de caso no hospital X," Persp.online: exatas \&eng., Campos dos Goytacazes, vol. 3, no. 6, pp. 56-72, 2013.

[13] A. L. Pereira and S. R. Pereira, "A cadeia de logística reversa de resíduos de serviços de saúde dos hospitais públicos de Minas Gerais: análise a partir dos conceitos da nova Política Nacional de Resíduos Sólidos Urbanos Desenvolvimento e Meio Ambiente," no. 24, pp. 185-199.

[14] A. Pruss-Ustun et al. (2013). Safe management of wastes from health care activities. World Health Organization, Geneva. [Online]. Available:

http://www.healthcarewaste.org/fileadmin/user_upload/resources/Safe -Management-of-Wastes-from-Health-Care-Activities-2.pdf

[15] E. Titto, A. A. Savino, and W. K. Townend, "Healthcare waste management: the current issues in developing countries," Waste Manag. Res. J. Int. Solid Wastes Public Clean. Assoc., 2012.

[16] UNEP/SBC. (2004). Preparation of national health-care waste management plans in sub-saharan countries guidance manual secretariat of the basel convention and, secretariat of the basel convention and world health organization. [Online]. Available: http://www.who.int/water_sanitation_health/medicalwaste/en/guidanc emanual.pdf

[17] M. S. Hossain, A. Santhanam, N. A. Norulaini, and A. K. Omar, "Clinical solid waste management practices and its impact on human health and environment - A review," Waste Management, vol. 31, no. 4, pp. 754-766, 2011.

[18] M. Carniato, T. Tudor, and M. Vaccari, "International governance structures for health-care waste management: A systematic review of scientific literature," Journal of Environmental Management, vol. 153, 2015.

[19] E. S. Windfeld and M. S. Brooks, "Medical waste management - A review," Journal of Environmental Management, vol. 163, 2015.

[20] T. Tudor. Comparison of healthcare waste management planning in "developed" and "developing" countries". [Online]. Available: http://www.eoearth.org/view/article/151402/

[21] D. C. Wilson, "Development drivers for waste management," Waste Manag. Res., 2007, vol. 25, no. 3, p. $198 \mathrm{e} 207$.

[22] G. Ruoyan et al., "Investigation of health care waste management in Binzhou District, China," Waste Management, 2010, vol. 30, pp. 246-50.

[23] A. P. Ananth, V. Prashanthini, and C. Visvanathan, "Healthcare waste management in Asia," Waste Management, vol. 30, 2010, 154-161.

[24] S. C. Joshi, V. Diwan, A. J. Tamhankar, R. Joshi, H. Shah, M. Sharma, A. Pathak, R. Macaden, and C. S. Lundborg, "Staff perception on biomedical or health care waste management: A qualitative study in a rural tertiary care hospital in India," PLOS ONE, May 29, 2015.

[25] United Nations General Assembly, "Report of the special rapporteur on the adverse effects of the movement and dumping of toxic and dangerous products and wastes on the enjoyment of human rights," Calin Georgescu, Report A/HRC/18/31, pp. 1-2, 2011.

[26] P. M. Nóbrega, "Gerenciamento de resíduos sólidos de serviços de saúde: Um estudo de caso," Trabalho de Conclusão de Curso Monografia apresentada ao Departamento de Estudos da Escola Superior de Guerra como requisito à obtenção do diploma do Curso de Altos Estudos de Política e Estratégia Escola Superior de Guerra, 2012.

[27] Brazil, Ministry of Health, Sanitary Vigilance Agency. (2004). Resolution - RDC $\mathrm{n}^{\circ}$ 306/2004. [Online]. Available: http://portal.anvisa.gov.br

[28] E. A. Silva, R. C. Shiga, and L. Colares-Santos, "Gestão de resíduos em clínicas odontológicas privadas em Presidente Prudente/SP," Revista Nacional de Gerenciamento de Cidades, vol. 3, no. 16, 2015, pp. 53-68.

[29] D. N. Nogueira and V. Castilho, "Resíduos de serviços de saúde: Mapeamento de processo e gestão de custos como estratégias para sustentabilidade em um centro cirúrgico," REGE-Revista de Gestão, 2016.

[30] N. Mozachi, "O Hospital: manual do ambiente hospitalar," Curitiba: Editora Manual Real, 2007. 
[31] Brazil, Ministry of the Environment. (2005). National Environment Council (NEC). Resolution 358/2005. [Online]. Available: http://www.mma.gov.br/port/conama/legiabre.cfm?codlegi=281

[32] R. Sushma, S. Naganandini, and D. Nagabhushana, "Issues impacting dental hospital waste," Indian J.dent Adv., 2012, vol. 4, no. 2, p. 814.

[33] L. B. Moraes, "Resíduos odontológicos em unidades de PSF: Uma reflexão sobre o gerenciamento na atividade clínica e na assistência domiciliary,” 2014. M.S. thesis - Escola Nacional de Saúde Pública Sérgio Arouca (ENSP), Rio de Janeiro, 2014.

[34] Brazil, Establishing the National Policy on Solid Waste, Amending Law No. 9,605, February 12, 1998.

[35] M. F. Bassani and J. Macke, "A logística reversa e a responsabilidade social nas empresas," Revista de Administração e Comércio Exterior, vol. 2, no. 1, pp. 61-74, 2016.

[36] J. L. S. Cometti and I. T. G. Alves, "Responsabilização pós- consumo e logística reversa: o caso das embalagens de agrotóxicos no Brasil," Revista Sustentabilidade em Debate, vol. 1, no. 1, 2016.

[37] REVLOG - European Working Group on Reverse Logistics. (2009). [Online]. Available: http://www.fbk.eur.nl/OZ/REVLOG/

[38] A. Brunetto and M. G. Passos, "Logística reversa de pneus inservíveis: Estudo de caso no município de xanxerê-Sc," $L A J B M$, vol. 6, no. 3, pp. 20-44, 2015.

[39] H. K. T. Campos, "Renda e evolução da geração per capita de resíduos sólidos no Brasil," Eng. Sanitária. Ambiental, vol. 17, no. 2, pp. 171-180, 2012.

[40] C. M. D. F. Marchi, "Cenário mundial dos resíduos sólidos e o comportamento corporativo brasileiro frente à logística reversa," Perspectivas em Gestão \& Conhecimento, João Pessoa, vol. 1, no. 2, pp. $118-135,2011$

[41] J. C. A. Mendonça, L. B. O. Nobre, and E. L. Casarotto, "A logística reversa e sua importância como fator determinante para as organizações no cenário da cadeia de suprimentos do setor sucroalcooleiro," XIX Simposio De Adminstração da Produção, Logistica e Operações Internacionais, Sao Paulo 2016.

[42] Brasil, Ministry of Health, Sanitary Vigilance Agency. (2002). Resolution - RCD $n^{\circ}$ 50/2002. [Online]. Available: http://portal.anvisa.gov.br

[43] C. L. C. Lui and S. Aquino, "Logistica reversa: Como reaproveitar placas de petri no fluxo de trabalho de um laboratório de microbiologia," Anais do III SINGEP e II S2IS - São Paulo - SP Brasil, 2014.

[44] T. S. Oliveira and M. A. Musetti, "Revisão Compreensiva de logística hospitalar: Conceitos e atividades," Revista de Gestão em Sistemas de Saúde-RGSS, vol. 3, no. 1, Janeiro/Junho, 2014.

[45] R. A. Maranhão, M. T.S. Souza, and C. E. Teixeira, "Gestão de resíduos de serviço de saúde em organização militar: um estudo de caso na marinha do Brasil," Revista de administração hospitalar e inovacão em saúde, pp. 44-59, 2014.

[46] R. C. Castro et al., "Gerenciamento dos resíduos de serviços de saúde em um hospital de pequeno porte," Rev Rene, 2014, vol. 15, no. 5, pp. 860-868.

[47] L. L. Sampaio and S. S. A. Filho, "Gerenciamento de resíduos de películas de chumbo de serviços odontológicos em Salvador, Bahia," Revista Eletrônica de Gestão e Tecnologias Ambientais (GESTA), vol. 2, no. 1, pp.163-171, 2014.

[48] M. Ozbek and F. D. Sanin, "A study of the dental solid waste produced in a school dentistry in Turkey," Waste Manag., 2004, vol. 24, no. 4, pp. 339-345.

[49] E. Kizlar, N. Iosifidis, E. Voudrias, and D. Panagiotakopoulos, "Composition and production rate of dental solid waste in Xanthi, Greece: variability among dentist groups," Waste Manag., 2005, vol. 25 , no. 6, pp. 582-591

[50] T. R. Santos, E. M. F. M. Rocha, R. M. Rocha, and R. A. Portela, "Acondicionamento dos Resíduos Sólidos dos Serviços de Saúde nas Unidades Básicas de Saúde (Ubs) do Município de Caicó/RN," Revista Brasileira de Geografia Médica e da Saúde, vol. 10, no. 18, pp. 46-57, Jun. 2014.

[51] T. Hanne, T. Melo, and S. Nickel, "Bringing robustness to patient flow management through optimized patient transports in hospitals," Interfaces, vol. 39, no. 3, pp. 241-255, 2009.

[52] R. J. Vidmar. (August 1992). On the use of atmospheric plasmas as electromagnetic reflectors. IEEE Trans. Plasma Sci. [Online]. 21(3). pp. 876-880. http://www.halcyon.com/pub/journals/21ps03-vidmar

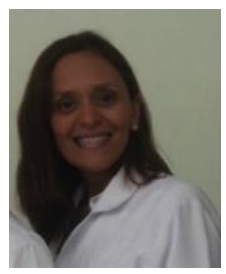

Eliane de Oliveira Aranha Ribeiro was born in 1967. She is a master's degree student of industrial engineering in Federal University of Amazonas, Brazil. Her current research interests are in health-care waste management and environmental management.

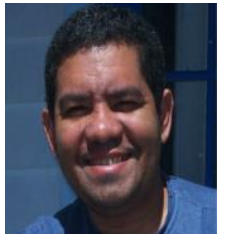

Raimundo Kennedy Vieira was born in 1971. He received his PhD degree in chemistry from Campinas State University (Unicamp). He is currently the Coordinator of Industrial Engineering Master Program in Federal University of Amazonas, Brazil. $\mathrm{He}$ specializes in environmental management. 